\title{
Svar til Marianne Egeland
}

\section{Kunsten å skrive om Hamsunsenter-planer i nord og sør}

\author{
Alvhild Dvergsdal
}

I artikkelen "Hamsun i sør og Hamsun i nord"i Nordic Museology 2020/1 analyserer Marianne Egeland Hamsunsenter-planer i Hamarøy og Grimstad i fire prosjekt-beskrivelser, to fra hver. Planene er:

- Prosjektbeskrivelse fra Grimstad fra 2005 for et Ibsen-Hamsun-senter

- Anbefaling fra 2017 om et Hamsunmuseum i Grimstad

- Virksomhetsplan for Hamsunsenteret, 2005

- Grunnbok Hamsunsenteret, 2008

I artikkelen framsettes en del påstander som jeg vil imøtegå.

Egeland søker gjennom analysene "innsikt i hvordan man tenkte at Hamsun bør formidles i museumssammenheng" (Egeland, 43); nærmere bestemt svar på spørsmålet: "hvilke strategier legges det opp til for å selge den Nobelprisvinnende dikteren som måtte svare i retten for sin støtte til Hitler og okkupasjonsmakten under andre verdenskrig?" (Egeland, 43). Samt svar på: "Hvorfor strandet planene i Grimstad, men lot seg gjennomføre på Hamarøy?" (Egeland, 42-43).

Egeland finner at apologetiske strategier gjør seg gjeldende i samtlige planer: Ubehagelige forhold rundt Hamsuns NS-, Quisling-,
Goebbels- og Hitler-støtte i siste del av hans liv blir gjennomgående bagatellisert, kontekstualisert bort, forbigått og ufarliggjort, mens den skjønnlitterære forfatteren dyrkes, ${ }^{1} \mathrm{i}$ den hensikt å gjøre prosjektet spiselig for opinion og beslutningstakere og dermed realiserbart.

Ja, om Hamsunsenterets totale virksomhet hevdes det sågar at en apologetisk holdning "gjennomsyrer" den fram til i dag (Egeland, 52)! - altså at alt Hamsunsenteret har gjort og produsert gjennom 10-årsperioden det har eksistert, fokuserer skjønnlitterær storhet og dysser ned politiske skyggesider. Noen form for nærstudium av senterets virksomhet eller noe slags belegg for påstanden gir Egeland imidlertid ikke, tvert imot poengteres at senterets utstilling - en sentral del av et litterært senters virksomhet - ligger "utenfor denne undersøkelsen" (Egeland, 51).

På lignende måte er andre beskyldninger til stede i Egelands artikkel som verken springer ut av planmaterialet, er belagt i kilder, eller følger av egen research, og som dermed kan synes å bunne i spekulasjoner eller fordommer.

Manglende overensstemmelse mellom spørsmål det søkes svar på, og valgt materiale og metode viser seg blant annet i behandlingen av spørsmålet om hvorfor Hamarøy fikk, men Grimstad ennå ikke har fått, sitt besøkssted for Hamsun. Spørsmålet krever åpenbart under- 
søkelser av mer enn de fire plantekstene - av historikk, søknadsprosesser og offentlig kommunikasjon og debatt rundt planene. Men dette mangler. En artikkel om Grimstads jubileum i 2009 refereres, enkelte avisinnlegg nevnes, en anmeldelse/studie av Tore Rems bok fra 2014, og et par omtaler av bøker av Hamsun, men referansene synes sporadiske og tilfeldige. Viktige biter av svar på spørsmålene som stilles, går da nødvendigvis tapt.

Et eksempel er Egelands manglende research på den kronglete veien fram til realiseringen av Hamsunsenteret på Hamarøy. Egeland kaller feilaktig avsenderne bak virksomhetsplanen 2005 "initiativtakere", og synes å mene at planenes foranledning er det kommende 100-årsjubileet for dikterens fødsel (2009). Men ideen om et dokumentasjonssenter for Hamsun ble lansert første gang i 1984. Hamsunsatsingen på Hamarøy startet med åpningen av et museum på Hamsund allerede i 1959, i hjemmet til ekteparet Johnsen som da bodde der. Forfatteren, motstandsmannen og antinazisten Lars Berg var støttespiller. Han hadde sittet på Grini under krigen, var opptatt av forsoning og støttet Hamsunfamilien i en vanskelig tid. En rekke andre ildsjeler og personligheter fra Hamarøy og Nord-Norge spiller viktige roller i senterets forhistorie, blant andre Elvine Skavikeng, Aslaug Vaa, Nils-Magne Knutsen, Alf Einar Øien, Rolf Steffensen, May Valle, Helga Wiik. Hamsundagene på Hamarøy startet i 1982, Hamsun-selskapet ble opprettet 1988. Hamarøy teaterlag (1983) dramatiserte, regisserte og satte opp Hamsun-romaner i en årrekke. I denne langstrakte historien ville Egeland ha funnet viktige deler av et svar på spørsmålet om hvorfor Hamsunsenteret ble en realitet: Det handler om et sterkt, lokalt og regionalt engasjement og kunnskapsnivå bygd opp over lang tid. Engasjementet innebar til dels stor uenighet og krevende debatter rundt spørsmål angående senterets hva, hvorfor og 93 hvordan (Vaa et. al. 2010).

Men i stedet for å faktisk undersøke historikken, gripes det til spekulasjoner. Ifølge Egeland skyldtes senterets realisering på Presteid i Hamarøy, dette "lille tettstedet med noen ganske få innbyggere" (Egeland, 48) en nordlandsk, bevisstløs, antydningsvis lysebrun resepsjon av dikteren. Et "avgjørende premiss" for beslutningen om å bygge senteret er nemlig, ifølge Egeland, at "for beboere, næringsliv og myndigheter i regionen representerer Hamsun en merkevare tilsynelatende upåvirket av landssviket og brun ideologi" (Egeland, 48).

Her har det gått fort i svingene. Som om krigsårene var mindre vonde og hadde etterlatt færre traumer i nord enn i sør? Tyske kystfort lå på rad og rekke oppover langs kysten og skapte frykt og vanskelige hverdager - Fort Dietl rett sør, Adolf-kanonen ved Harstad. Russiske krigsfanger bygget jernbane nordover fra Fauske, flere fangeleirer lå i Hamarøy. Nordnorske byer ble bombet sønder og sammen. I Narvik førtes det felttog med store sivile tap. Finnmark og Nord-Troms ble brent og tvangsevakuert i krigens sluttfase, med store lidelser for befolkningen. Noen av de evakuerte ble internert i Hamarøy, noen av dem ble boende. Krigsseilerhistorie rammet hardt også i nord. Så skal det likevel ha gått upåaktet hen i regionen at Knud Pedersen fra Hamsund, senere Nobelprisforfatteren Knut Hamsun på Nørholm, agiterte for Hitler-Tyskland, pleiet omgang med okkkupasjonsmakten, håpet på tysk seier, gav Nobelmedaljen til Hitlers propagandaminister Joseph Goebbels, og publiserte en høystemt nekrolog over Hitler 7. mai 1945? Knut Hamsun, som skrev om Kristiania og om nordnorsk natur og kultur på måter som ikke før hadde vært gjort, og representerte nasjonal og regional stolthet ved sin Nobelpris i 1920, 
skal ikke han dermed ha skapt dilemmaer og konflikter for folk i nord? Nei, mener Egeland, for nordlendingene var det det samme med alt dette så lenge de kunne tjene på ham. Skyldes disse påstandene manglende kunnskaper om krigen i nord, lav tro på nordboeres politiske og etiske bevissthet, svake fagfellevurderere, eller et kildemateriale som ikke nevnes? Poenget utdypes videre: "For dem" ("beboere, næringsliv og myndigheter i regionen")

er nazisten Hamsun rett og slett for en herregårdsbesittende søring å regne [... ]. Nordlendingenes Hamsun er den unge fattiggutten som slo seg frem ved hjelp av sitt enestående talent. At han skrev nedlatende om samer, landsdelens urbefolkning, har blitt mer problematisk senere, men svekket ikke merkevaren den gang ... . (48)

Her vites det tydeligvis hva "nordlendingene" tenker om saken. Basert på hva?2 Bildet av griske, uvitende og ureflekterte nordnorske innfødte sementeres til slutt i følgende artige spekulasjon:

Det spørs imidlertid om vi ikke kunne ha funnet Hamsun på regionale nordnorske sedler, dersom det hadde eksistert en slik valuta. (Egeland, 48)

Egeland peker på innslag av opphavsmytisk metaforikk i planenes argumentasjon. Det er i og for seg interessant. Men er det nødvendigvis "galt"? Egeland "avslører" altså at et geografisk argument trekkes inn, om at senteret burde ligge akkurat her, på Hamarøy eller i Grimstad, ut fra dikterens tilknytning til stedene. Egeland finner argumentet utidig, fordi: "da må alle andre steder utelates" (Egeland, 46)! Men det er vel nettopp det som er poenget i en slik plan, å argumentere for hvorfor senteret bør ligge nettopp her - og ikke der. Var budskapet at senteret kunne ligge både her og der, ville det være svært underlig. Egeland tar siden overraskende nok rollen som djevelens advokat og hevder opphavsmytisk (mot)argumenterende at det geografiske argumentet ikke holder fordi Hamsun jo faktisk ble født i Lom. Og Nørholm lå ikke i Grimstad kommune da Hamsun bodde der, men i Eide kommune! Og som guttunge mistrivdes Knud Pedersen på Presteid. Altså med andre ord, oppfyller ikke Hamarøy/Presteid eller Grimstad opphavsmytens argument nok?

Egeland peker videre på at det spilles på Askeladden-analogier i den innledende skildringen i 2005-planen, som hun kaller "Hamarøy-myten": Om den begavede fattiggutten Knud som lyktes til slutt etter mange år med lidelse og hardt arbeid. Eventyrassosiasjonene er åpenbare, og det stemmer nok at analogien appellerer. Analogien blir imidlertid feil, mener Egeland, fordi Hamsun fikk jo hjelp underveis, og dessuten led Hamsun "neppe mer enn andre dikterspirer" (Egeland, 46). Nå er det vel strengt tatt slik at hjelpere var noe som også Askeladden hadde, og at Knud så vel som Askeladden faktisk var fattiggutter som nådde sitt mål ved iherdighet, stahet, freidighet, og hjelp fra andre. Avvik fra analogien er det selvsagt, for eksempel Hamsuns utakknemlige oppførsel senere mot hjelperen Zahl. I det hele tatt er det svært mye som ikke er likt mellom Askeladden og Hamsun. Det hadde vært interessant å lese mer om når og hvorfor det blir "feil" å bruke analogi på denne måten i en argumenterende tekst.

Egelands analytiske blikk styres av antagelsen at apologetiske strategier nødvendigvis preger materialet, ut fra resonnementet at

et Hamsun-dyrkende, litteraturinteressert publikum, som tilsvarte viktige deler av det stipulerte besøksgrunnlaget, må antas å ha vært varierende motivert for å få heltebildet sitt forstyrret av ubeha- 
gelige realiteter som handler om nazisme og antisemittisme. (Egeland, 48, min kursiv.)

For å få antagelsen bekreftet, må hun vise manglende eller bagatelliserende omtaler av "nazisten Hamsun" i tekstene som analyseres. En rekke spissfindige tekstkommentarer blir ett av resultatene, som påpekningen av at Hamsuns "støtte til nazismen nevnes [på Hamsunsenterets hjemmeside], men løftes ikke frem" (Egeland, 52, min kursiv). Når Egeland i Grimstads plan for et Hamsunmuseum (2017) finner at de

problematiske sidene ikke underslås, og arbeidsgruppen peker så vel på Hamsuns støtte til Nasjonal Samling [...] som på konflikter han hadde med lokalbefolkningen,

så er det likevel ikke godt nok, det er nemlig ikke "mer enn det som vel kan anses som påkrevet" (Egeland, 53)! Når Grieg kalles "stalinist", mens Hamsun kalles "nazisympatisør" i samme plan, ser Egeland en avledende manøver fra sannheten om "nazisten Hamsun". Og hun finner stråmannsargumentasjon $\mathrm{i}$ formuleringen "samtidig er det viktig å huske på at Hamsun var og er mer enn nazisten Hamsun" (Egeland, 53). For hvem mener nå at Hamsun først og fremst var nazist? spør Egeland meget retorisk.

Selv ikke det at hele andre etasje i de gamle tingretts-lokalene i Grimstad, ifølge 2017-planene skal tas i bruk for å tematisere Hamsuns politiske rolle og etterspillet på 30- og 40-tallet, får anerkjennelse av Egeland, på grunn av en setning om at man samtidig ikke vil gjøre hele huset til et lokalt krigsmuseum. Men hvorfor ikke det? spør Egeland. Og gjør en argumentatorisk saltomortale idet hun spør

om rimeligheten i den implisitte slutningen at et eventuelt krigs- eller ideologikritisk museum ville innebære å sette dikteren i et verst tenkelig lys.

(Egeland, 54)

Her er likevel Egeland inne på noe (som står i motstrid med hennes hypotese om det motsatte): Saken er at det å tematisere Hamsuns politiske rolle før, under og etter krigen på etterrettelig vis, det engasjerer og berører publikum idag. På Hamsunsenteret opplever vi besøkende som kommer tilbake fra utstillingen med tårer i øynene fordi det blir sterkt å konfronteres med de mange, delvis brutale sannhetene og sidene ved Hamsun.

Grunnboken for Hamsunsenteret på Hamarøy brukes det mest plass på å analysere. Dette er ikke en argumenterende tekst, men et internt dokument og en faglig betenkning skrevet av en fagruppe der blant annet professor Atle Kittang deltok, angående retningslinjer for senterets utstillings- og formidlingspraksis. ${ }^{3}$ Grunnboken i sin endelige form ble ferdig i 2008, altså etter at Hamsunsenteret ble besluttet bygget. ${ }^{4}$

Grunnboken flagger eksplisitt en anti-apologetisk strategi: Det komplekse og det kontroversielle ved Hamsuns liv og forfatterskap skal utstilles og politiker og dikter ikke holdes adskilt. Det skal skje ved krasse kollisjoner mellom ulike innfallsvinkler til det samme eller motstridende aspekter ved Hamsuns liv og forfatterskap, uten å forsøke å harmonisere i tolkende overbygninger. Ved det må besøkende selv forholde seg til og reflektere over også de ubehagelige elementene i historiene om Hamsun. Utstillinga anbefales organisert i tematiske stasjoner framfor en ubrutt kronologisk (monologisk) linje. Grunnboken vektlegger altså diversitet og polyfoni som strategi ved senterets formidlingsmåte(r) og bekrefter med andre ord åpenbart ikke Egelands hypotese om apologese. Noe Egeland nevner. Men hun lar seg ikke stoppe av slikt: "Ikke desto min- 
dre kan dokumentet leses som en strategi for bagatellisering og ufarliggjøring" (Egeland, 49)! Hun opplever et "regnestykke som ikke går opp", for Grunnboken er primært preget av Hamsun-resepsjonens apologetiske spor (Egeland, 48). Saken er at Egelands "avsløring" av at den virkelige strategien i Grunnboken er å overse og bagatellisere Hamsuns nazifisering og landssvik, skjer ved å overse og bagatellisere alt i Grunnboken som motstrider påstanden; ved hente fram tekstbiter fra Grunnboken som leses på tvers av kontekst og intensjon, og ved å finne en form for skjult argumentasjon.

\section{NOEN EKSEMPLER:}

Egeland hevder at ufarliggjørende kontekstualiseringsteknikker er gjennomgående strategi i Grunnboken. Til tross for en rekke forslag om det motsatte, som montering av radikalt motstridende og provoserende sider av Hamsun i utstillingen. Hvor er den kontekstualiserende strategien i et forslag som dette, skrevet under overskriften "Utenrikspolitiske holdninger":

For å få fram det vanvittige paradokset, kan vi for eksempel sette Kraft durch Freude-plakat i en slags montasje sammen med bilder fra de russiske fangeleirene (utryddingsleire) i Nordland. Fangeleire som lå like ved der Hamsun begynte skrivingen av Markens grøde. Og så kanskje nekrologen over Hitler midt oppi det hele. (Grunnboken, 122)

\section{HVOR ER UFARLIGgJøRINGEN I DETTE FORSLAGET?}

Egeland hevder at en romantisk diktermyte ligger i bunnen av Grunnbokens formidlingsplan. Til tross for at det poengteres i Grunnboken at senterets utstilling "ikke dreier seg om genidyrking, men om politisering og ak- tualisering (men altså gjerne problematisere genidyrking som en form for politisering)" (Grunnboken, 24).

\section{EGELAND SITERER FRA GRUNNBOKEN:}

I Hamsun-resepsjonen har det som vi vet vært prekært å skille mellom poeten og politikeren, en apologetisk leserstrategi som begynte med Nordahl Griegs "det dypeste i hans diktning er ubesmittet av det." Det er imidlertid et vanskelig skille. For hva er det dypeste i Hamsuns diktning? Om det er naturdyrkingen - så har jo også den sitt ideologiske motstykke (jf vitalisme). (Grunnboken, 46)

Hun leser dette som et uttrykk for at Hamsuns diktning er "ubesmittet" av politikk og at den skjønnlitterære forfatteren går fri for alt politisk og biografisk grums. Men i sitatet er det jo dette synspunktet som tematiseres og diskuteres. Noen avsnitt lenger ut brukes samme sitat som grunnlag for å hevde at Grieg "utropes til pionér" for senterets egen holdning.

$\AA$ kalle relasjonen forfatter-fascist et "paradoks", og Hamsun "gåtefull", er avledende og ugrei språkbruk ifølge Egeland. Hun mener at fordømmelse utvannes med slik språkbruk (Egeland, 51). Hun er på lignende vis mistenksom til formuleringer som "dobbelthet", "tvetydig" og varianter av "motsetning/motsatt", da de insisterer på et mangfold som hun ikke finner: "hvor flerstemmig, dobbelttydig og ambivalent blir summen av alle elementene som inngår i fremstillingen?” (Egeland, 50). Er vi kanskje her inne på en hovedsak: For Egeland er forfatteren Hamsun = nazisten Hamsun. Bildet av kompleksitet i Grunnboken er dermed i seg selv misvisende for Egeland, og ensidig fordømmelse (av nazisten) bør være målet for formidling av Hamsun. Det er det naturligvis lov å mene, men synspunktet burde i redelighetens navn tydeliggjøres som 
grunnlag for resonnementene, kritikken og tolkningene.

Heller ikke karakteristikker i Grunnboken som "kontroversiell", "omstridt", "outsider" brukt om Hamsun, overbeviser Egeland, fordi benevnelsene i bunn og grunn er for "honnørord å regne" (Egeland, 51).

Grunnboken advarer mot nedtoning av Hamsuns politiske valg. Det anbefales bl.a. at første stasjon tematiserer Hamsuns ettermæle, altså tiden etter Hamsuns politiske fall, for å "oppnå en umiddelbar politisering av Hamsun, og samtidig får reist spørsmålet om forholdet mellom litteratur og politikk, mellom diktning og polemikk. Dette er sentrale mål for Hamsunsenteret" (Grunnboken, 39, min kursiv). Dette er et sterkt og anti-apologetisk grep. Men Egeland finner like fullt skjult uttrykk for apologese fordi det står at publikum skal " $f a ̊$ grep om" dobbeltheten fra første stund (Egeland, 50, min kursiv.) Så er det altså likevel ikke snakk om "tanker som skal strides, men et ønske om å styre og kontrollere publikum og påvirke de besøkendes reaksjon", som er den overordnede kommunikasjonsstrategien?" spør hun retorisk (Egeland, 50-51). Når så Grunnboken faktisk til alt overmål foreslår å tematisere "Vandreren" på samme stasjon som Ettermælet, for å nettopp ikke styre publikum for mye, så mistenkeliggjøres også det: "Heller enn å bli konfrontert med en politisert Hamsun kan de besøkende begynne med hans første reise til Hamsun og/eller vandrermotivet." (Egeland, 51)

Er saken i bunn og grunn i denne artikkelen at alt uansett er gærent når det gjelder Hamsunsteder og -formidling, for det gale er at det i det hele tatt ønskes? Er det endatil diktersentre og forfattermuseer som sådan Egeland er imot? Jamfør underoverskriften: "Kunsten å argumentere for et diktersenter" og utbruddet mot "at det investeres store summer i å ruste opp forfatterhjem og bygges nye diktersentre, lenge etter at de aktuelle forfatterne opphørte å være folkelesning” (Egeland, 52). Bjerkebæk, Alstahaug m.fl. nevnes som eksempler. Det er også et interessant synspunkt! Men rent bortsett fra det faktum at store deler av Hamsuns skjønnlitteratur er levende også i dag, og leses av et internasjonalt publikum, så tilhører synspunktet en annen artikkel, en annen problemstilling, og en annen metode.

Et gjennomgående problem med Egelands artikkelprosjekt er altså at hennes mål ikke er å få innsikt og finne svar, men å bekrefte en hypotese om at argumentasjon for Hamsunsentre nødvendigvis må være apologetisk. Når en apologetisk strategi likevel ikke er så tydelig til stede i dokumentene som analyseres, gjøres tolkninger på tvers av intensjon og eksplisitt argumentasjon. Det skal sies at vi alle i bransjen av teksttolkning fort kan ramle i denne fallgruven, når egen tolkning avgjør bekreftelse/avkreftelse av egen hypotese.

Det skal også sies at Egeland modererer en del påstander underveis på ulike måter, bl.a. ved bruk av retoriske spørsmål som gjør det mulig å være påståelig og samtidig spørrende. Videre ved en rekke hypotetiske og usikkerhets-markerende utsagnsverb som "må antas", "kan ikke ha vært", "kan det argumenteres for", "kan ... leses som", "kunne lett oppfattes som". En del formuleringer stilles i anførselstegn uten kommentarer; leseren overlates å "finne feilene". Motsetninger i Egelands artikkel mellom dyrking av forfatter kontra kritikk av landsforræder, tenderer mot å utviskes mot slutten: "Hva som ville styrke turisme og næringsliv mest og fremme lokal identitet og stolthet best" enten det er "millionbevilgninger til dyrkingen av en landsforræder" eller et museum som viser "Nobelprisvinnerens handlinger før, under og etter krigen," "forblir usikkert" (Egeland, 54). Hun velger en forbausende generell og "snill" 
konklusjon etter sine bastante påstander om apologeser i Hamsunsenterplaner:

ikke bare selve kommunikasjonsprosessen [for formidlingen av et problematisk ettermæle] var avgjørende for om senterplanene lot seg gjennomføre, men også innholdet i merkevaren som skulle selges, et innhold gitt av historiske og geografiske omstendigheter og som nødvendigvis varierer med tid og sted. (Egeland, 54)

Og her er viktig kunnskapsstoff. Egeland gir Hamarøy-rapporten honnør for å være godt fundamentert med realistiske analyser, så alt er ikke helsvart. Det er sant at det er svært viktig for et forfattermuseum å ha et faglig nettverk som inkluderer akademiske forskermiljøer, noe både Hamarøy og Grimstad nyter godt av. Personlig bet jeg meg merke i, og skulle gjerne ha lest mer om, Egelands kritiske fokus på kontekstualisering som grep. Det handler om å $ø$ ke forståelse av en tekst på den ene siden ved å bringe kunnskaper om konteksten, som vel må anses som viktig og nødvendig. Samtidig kan kontekstualisering fungere som alminneliggjøring og dermed ansvarsfraskrivelse.

Egeland skriver mot slutten ironisk "forståelsesfullt" om manglende evne til å gjennomskue myter og apologetiske standpunkt hos prosjektledelse i Hamarøy, for:

hva det er rimelig å forlange av kritikk og myteknusing av et senter som skal gi de besøkende minneverdige, følelsesbaserte totalopplevelser, klare sine økonomiske forpliktelser og tilfredsstille næringspolitiske forventninger. Reiselivsproduktet må forvaltes med kløkt. (Egeland, 52)

Det stemmer at Hamsunsenteret, i tillegg til å være et nasjonalt senter for formidling og forvaltning av Hamsuns liv og forfatterskap, fungerer som reiselivsdestinasjon. Det er i vir- keligheten en svært interessant kombinasjon. En stadig økende gruppe oppdaterte og kulturinteresserte besøkende lar seg ikke avspise av trivialiteter, ensidige synspunkt, lettvinte forbigåelser av fakta, romantiske dikterkonsepter eller harmonisering og kontekstualisering som underslår ubehagelige sannheter. Mange har reist langt, mange er kunnskapsrike, og stiller høye krav til senterets formidling. Faktum er at presentasjoner av Hamsuns ulike slags tekster og meritter, i Grunnbokens ånd og med vett og forstand, noe vi har på Hamsunsenteret, åpner opp for aktuell og viktig etisk, estetisk, politisk og eksistensiell refleksjon. Vi får stadig tilbakemeldinger på at det oppfattes og verdsettes.

Men sannsynligvis er her blindpunkt. Vi og de fleste museer og sentre er veldig interessert $i$ a bli gått normere etter i sømmene ikke minst fra universitetets forskere. Bare sømmene da faktisk ettergås. For Hamsunsenterets del: Hva med en sammenligning mellom Grunnbokens anbefalinger og faktisk utstilling og formidling i de 10 årene det har eksistert? For det er sant at fine ord i planverk ikke skal tas for god fisk uten videre; det må jo gjenspeiles i konkret virksomhet. Vi er nå i ferd med utskifting og fornying av utstilling, så ekstra interessant ville det vært nå med en helhetsanalyse. Eller å se nøye på argumentene i denne anmeldelsen som tre av oss ansatte skrev av Tore Rems viktige bok i 2014. Artikkelen avfeies ganske lettvint av Egeland som "tåkelegging". Etter mitt syn en god og grundig anmeldelse. Vår tankegang var at boka fortjente et grundig studium; og at en anmeldelse som også inneholdt kritiske synspunkt var noe forfatteren tålte. Vi har da også godt samarbeid med Rem i ettertid. - Er kanskje tiden moden for å drøfte nærmere dette apologi-begrepet som ennå brukes for å slå andre Hamsunforskere i hodet? Det er vel en temmelig utbredt enighet i dag - om enn kanskje ikke alltid etterfulgt i praksis - om at skjønnlitteratur og sakprosa, dikter og politi- 
ker, fiksjon og visjon, ikke har absolutte grenser mot hverandre. Og om at Hamsun-forskere og -formidlere, som andre forskere og formidlere, må arbeide kontinuerlig med ikke å underslå smertefulle sannheter omkring sitt forskningsobjekt og søke å formulere seg så etterrettelig, edruelig og nyansert som mulig.

\section{Noter}

1. Eller som det står i engelsk abstract: "the initiators argue for celebrating an author who supported Hitler and the Nazis during the war." (Egeland, 42)

2. Ett case nevnes som understøttelse, nemlig det at Hamarøy videregående skole i 2003 endret navn til Knut Hamsun vgs., mens det ikke var mulig å få "selv en gatestubb sørpå” hos de edle siviliserte (Egeland, 48) oppkalt etter ham. Mon tro om Egeland kjenner den tøffe debatten i forkant av navneendringen?

3. Avdøde professor Atle Kittang kalles for øvrig, urettmessig respektløst, «Hamsunforvalter» av Egeland og omtales som en forsker som frikjenner det skjønnlitterære forfatterskapet for ideologisk grums.

4. Forprosjekt-rapporten fra 1993 ville derfor kanskje ha vært en mer brukbar tekst å studere - mindre omfangsrik, mer argumenterende, og dermed mer kompatibel med de tre andre tekstene. Både virksomhetsplanen av 2005 og "Hamsunsenter på Hamarøy" (1993) betoner Hamsuns nazi-tilknytning, men ikke som en hovedsak; en rekke andre reiselivs-relevante tema diskuteres, sammen med annet kunnskapsstoff knyttet til biografi og skjønnlitteratur.

\section{LITTERATUR}

Børset, Bodil et. al. 2014. "Hvor dypt bukket Hamsun?" Klassekampen 16. desember, 13-15. Børset, Bodil et. al. 2015. "Hamsun-apologeter?" Klassekampen 10. januar, 36.
Dvergsdal, Alvhild 2020. "Den ekstreme Hamsun."

Nett-foredrag i samarbeid med Stiklestad

Nasjonale Kultursenter. https://hamsunsenteret. no/no/velkommen/?Article $=434$

Eck-Hansen, Lillian et. al. 1993. Hamsunsenter på Hamarøy. Forprosjekt 1993. Nordland Fylkeskommune.

Egeland, Marianne. 2020 "Hamsun i sør og Hamsun i nord. Kunsten å argumentere for et diktersenter." Nordisk Museologi 1, 42-56.

Estensen, Anita et. al. 2009. "Forhandling uten forsoning. En minnepolitisk studie av Hamsunåret 2009 i Grimstad." I Ottar Grepstad (red.): Forfattarens skriftstader. Litteræere museum i norsk minnepolitikk. Oslo: Samlaget, 212-248.

Estensen, Anita et. al. 2019. Forprosjekt for Hamsunmuseum i Grimstad. Grimstad, 1.6.

Gerhardsen, Anki 2018. "Hus for vanskelige samtaler." Klassekampen. 11.7. https:// arkiv.klassekampen.no/article/20180711/ ARTICLE/180719994?fbclid=IwAR2sn1OO_ DUpFMs7k292_ATmyt3APf4VzJ6fwz8dbzVTXVuiTQLLPNHZi9U

Harr, Karl Erik 2020. "Gøy på landet." Avisa Nordland, 10.8. Høivaag, Per 1995. ”Krigsveteraner i Hamarøy. ” I Børge Strandskog (red.): Årbok for Hamarøy. Hamarøy Historielag, 49-52.

Olsen, Øyvind A 2020. "Kritiserer Hamsunsenteret: - Bidrar til nye kaskader av skam over Hamsun." Avisa Nordland, 3.10., 21-22.

Saugestad, Frode 2020. "Hvorfor feirer vi ikke Hamsun?" Kronikk, Aftenposten, 27.5. https://www.aftenposten. no/meninger/kronikk/i/LAwQ94/hvorfor-feirer-viikke-hamsun-frode-saugestad Vaa, Aaslaug et. al. (red.) 2010. Hamsun, Holl, Hamarøy. Lars Müller Publishers.

Alvhild Dvergsdal, Ph.D. Tidligere professor ved Nordisk institutt, Universitetet $i$ Bergen, fra 2017 ansatt som fag-og forskningsleder ved Hamsunsenteret. 